\title{
The ostracod fauna from the Maastrichtian white chalk of Denmark
}

\author{
NIELS OLUF JØRGENSEN
}

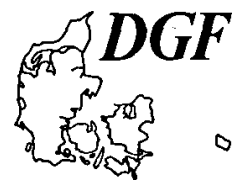

\begin{abstract}
Jørgensen, N. O.: The ostracod fauna from the Maastrichtian white chalk of Denmark. Bull. geol. Soc. Denmark, vol. 27, pp. 93-98, Copenhagen, March 23rd, 1979. https://doi.org/10.37570/bgsd-1978-27-09

The ostracod fauna from the Maastrichtian white chalk of Denmark includes 95 species representing 34 different genera. The qualitative composition is rather homogeneous throughout the strata studied, indicating a mature and well-balanced community in middle to outer shelf environments. Two biozones in the Danish Maastrichtian are established on the basis of ostracod species.
\end{abstract}

Niels Oluf Jørgensen, Institut for historisk Geologi og Palaontologi, Østervoldgade 10, 1350 København K, Denmark. February 21st, 1978.

The ostracod faunas in Upper Cretaceous sediments from north-western European basins have been intensively studied. Several large monographs have been published, including van Veen (1932, 1934, 1935, 1936, 1938), Bonnema (1940, 1941), Szczechura $(1964,1965)$, Deroo (1966) and Herrig (1966).

A thesis on the ostracods from the Maastrichtian white chalk of Denmark was written by the present author (Jørgensen 1970) and as one of the results of this study, two new species were described (Jørgensen 1974, 1976). The ostracod fauna from the Maastrichtian of Denmark shows close affinity to the fauna from the Lower Maastrichtian chalk of Rügen, East Germany described by Herrig (1966). The reader is referred to that paper for detailed taxonomy and synonyms. The present study deals with stratigraphical and palaeoecological aspects of the ostracod fauna within the Maastrichtian sequence in Denmark.

\section{Material}

The material studied originates from 20 outcrops or boreholes, 19 Danish and 1 Swedish, which fairly well represent the Maastrichtian sequence of white chalk in the Danish basin (fig. 1).

Samples were disintegrated by altemate boiling and freezing in destilled water or a supersaturated solution of glauber salt $\left(\mathrm{NaSO}_{4} .10 \mathrm{H}_{2} \mathrm{O}\right)$. All the ostracod valves were picked out under bino- cular microscope and determined to species. The specimens are in general well preserved.

\section{Faunal composition and ecology}

The ostracod fauna examined includes 95 species representing 34 different genera. A fauna list is

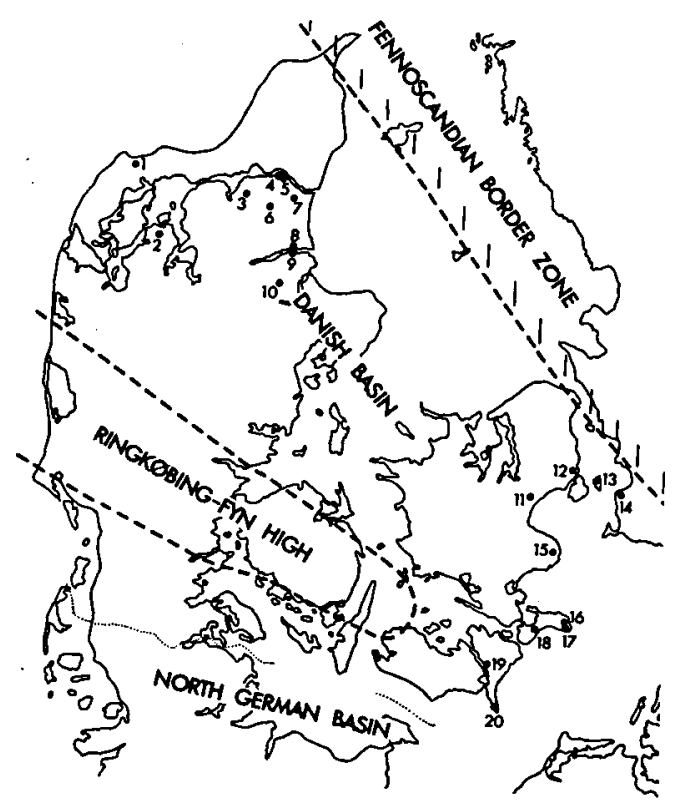

Fig. 1. Map of Denmark showing the localities studied in the present paper. 1. Bjerre; 2. Erslev; 3. Voxlev; 4. Rordal; 5. Danmark; 6. Ellidshøj; 7. Gudumholm; 8. Vive; 9. Dania Cement Works; 10. Spentrup; 11. Karlstrup; 12. Copenhagen TUBA 13; 13. Saltholm 13; 14. Limhamn; 15. Stevns; 16. St. Stejlebjerg; 17. Hvidskud; 18. Hvide Klint; 19. Hasselø; 20. Gedser. 


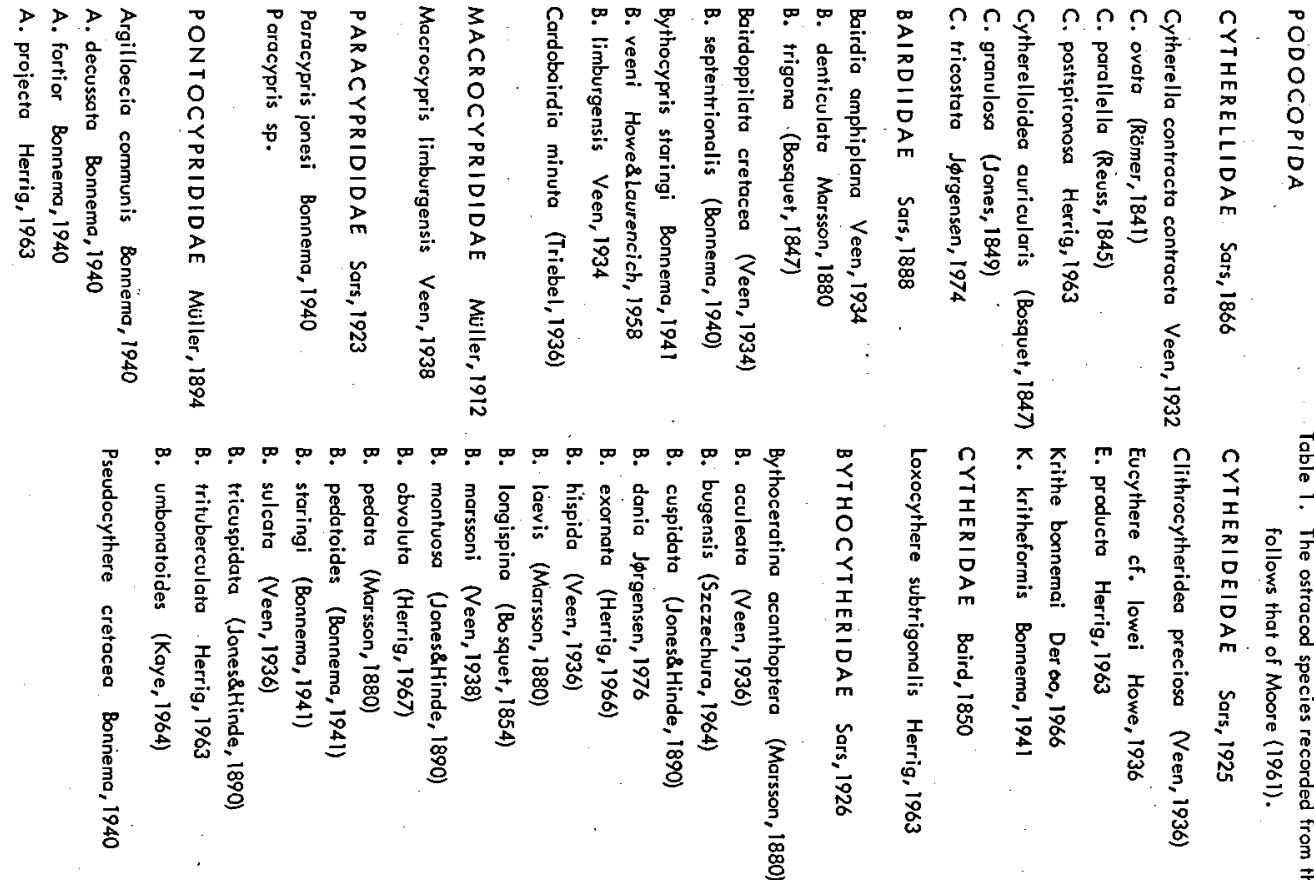

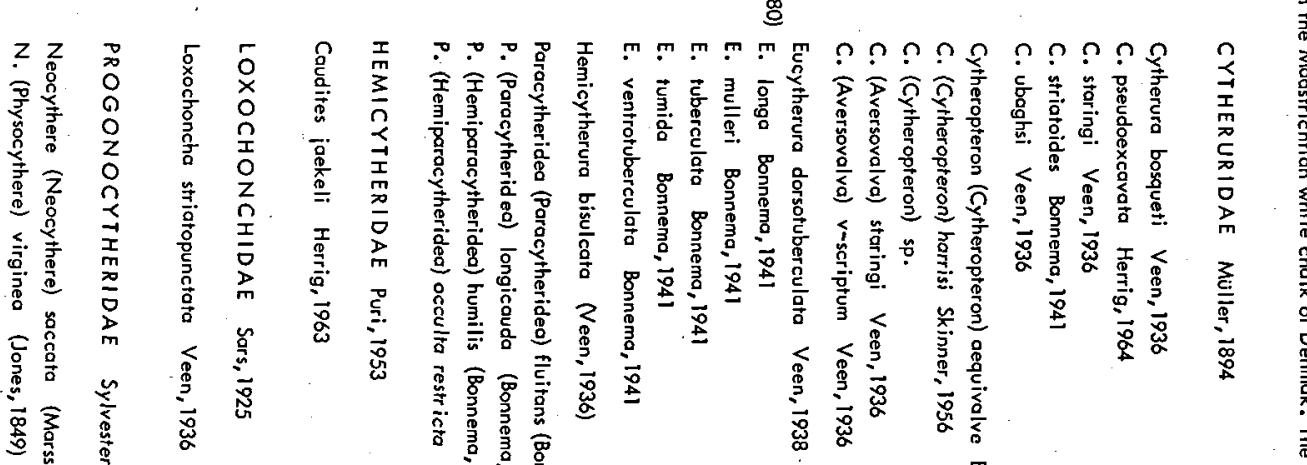

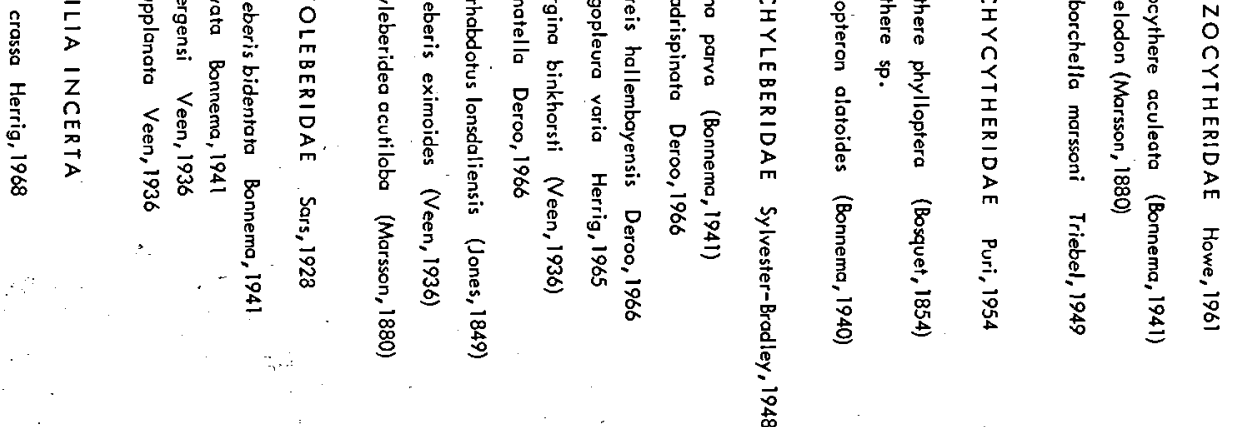


given in table 1 . The fauna is characterized by a remarkably uniform composition throughout the strata studied. The genera Bairdia, Cytherella, Cytherelloidea and Argilloecia are present in all samplex examined and are represented by several species and a large number of individuals. These genera dominate the fauna quantitatively.

Accessory species belong to the genera Krithe, Phacorhabdotus, Neocythere, Xestoleberis and Bythoceratina. Representatives of these genera may be rare or even absent in some samples, but occur in large numbers in a few samples where they constitute more than $15 \%$ of the entire number of specimens.

The genus Bythoceratina is a particularly important element in the fauna. It contains 19 different species i.e. approximately $20 \%$ of the number of species recorded and is morphologically the most variable genus in the material studied. The genus is represented in most samples, but by a varying number of species and individuals.

All other genera have a rather scattered and patchy distribution. The majority of these genera are represented by a few species only, and the number of individuals never exceeds $15 \%$ of the total number of specimens in a sample. Several are present in very few samples only. Though the rare species comprise only a minority of the total number of individuals, they make up more than $70 \%$ of the species recorded.

The quantitative distribution of valves of the dominant, accessory and rare species in two representative sections from Lower and Upper Maastrichtian is shown in fig. 2. The fauna is characterized by high diversity and a generally high density. The number of dominant species is rather constant within both sections, while the variation in number of species increases regarding the accessory and rare groups.

The density varies considerably in the strata studied. This was emphasized by a study of four samples from a well-defined level in the section at Dania Cement Works, which revealed a horizontal density variation similar to the vertical variation demonstrated in fig. 2.

A comparison between ostracod density and the relative size of the wash residue (WR), which reflects the quantitative size of the entire invertebrate fauna, does not reveal any correlation between these two parametres (fig. 2).
The main characteristic of the fauna is the rather uniform composition. Unfortunately there is no comparable Recent fauna and ecological considerations are therefore rather speculative. However, the significant dominance of smooth and lightly ornamented species combined with the silt-clay composition of the chalk sediment, is in good agreement with the correlation between carapace ornamentation and grain size distribution of substrate found by Elofson (1941) in a study of Recent ostracods from Skagerak. All genera are considered high marine and no species having an unquestionable affinity to plants have been recorded.

\section{Stratigraphy}

On the basis of ostracods a biostratigraphical subdivision of the Danish Maastrichtian can be established by two species only, Bythoceratina dania Jørgensen, 1976 and Bythoceratina umbonatoides (Kaye, 1964). The distribution of the two species in comparison with the known stratigraphy of the Danish Maastrichtian white chalk is shown in fig. 3.

B. umbonatoides is recorded from every locality that includes brachiopod zones $1-8$ and is one of the most frequent Bythoceratina-species in this part of the sequence. $B$. dania characterizes the uppermost Maastrichtian, being found in brachiopod zones 9-10 only (Jørgensen 1976). The species is quantitatively most frequent at localities in Jylland.

\section{Discussion}

A detailed biozonation of the Danish white chalk has been attempted by several authors. The most successful have been carried out on foraminifera (Troelsen 1937), belemnites (Birkelund 1957) and brachiopods (Surlyk 1970). A discussion of problems of chalk stratigraphy and ecology was published by Surlyk \& Birkelund (1977).

An evaluation of the quantitative and qualitative composition of the ostracod fauna outlined above does not allow any detailed stratigraphical subdivision of the Danish chalk. However, the chalk can be divided into two zones on the basis 


\section{"DANIA" CEMENT WORKS}

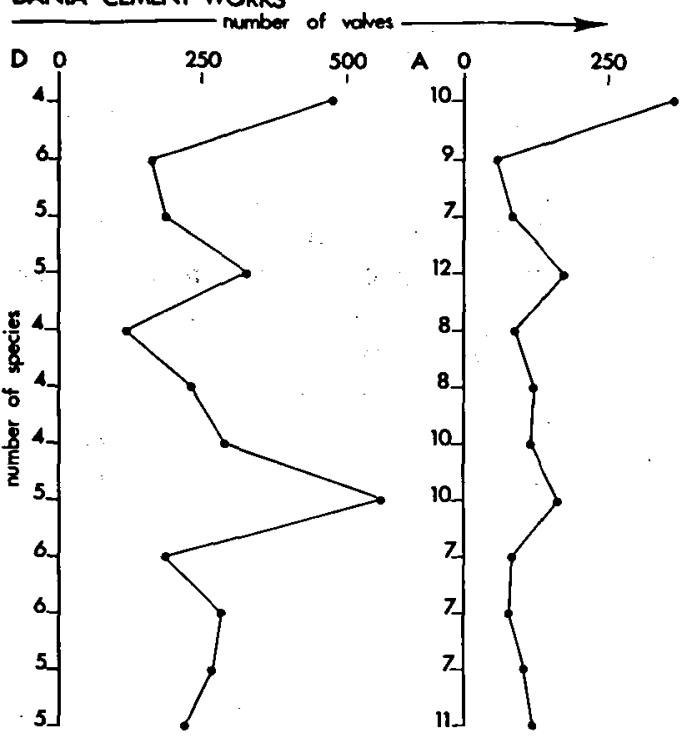

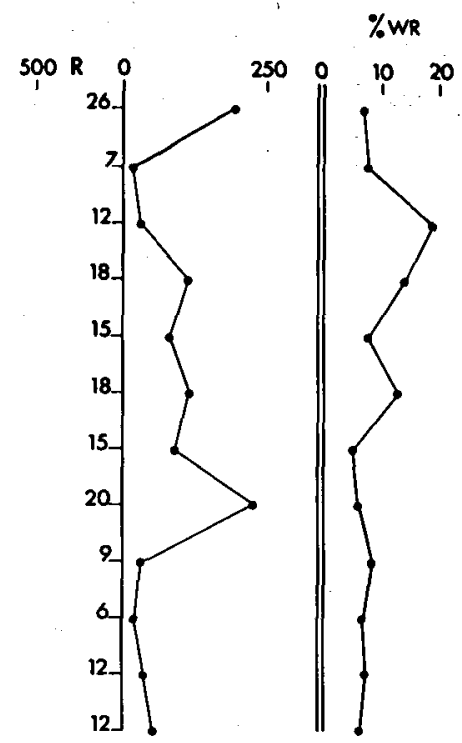

$\% W_{R}$

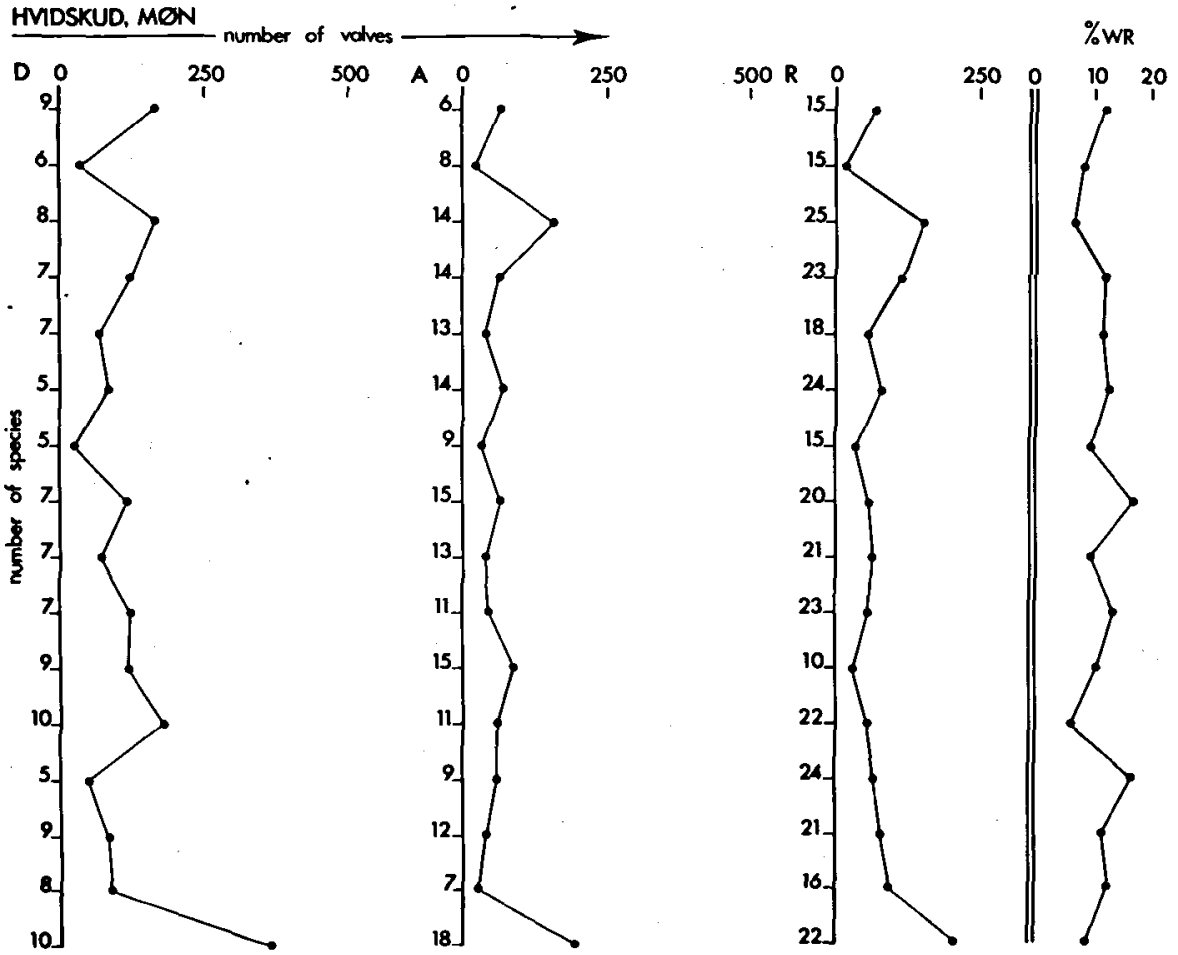

Fig. 2. The quantitative distribution of species and valves of ostracods in the section of Dania Cement Works (Upper Maastrichtian) and Hvidskud (Lower Maastrichtian). The figure shows for each $50 \mathrm{~g}$. sample the number of valves and the number of dominant $(D)$, accessory $(A)$ and rare $(R)$ species respectively. The ostracod distribution is compared to the wt* wash residues $(* w t)$ i.e. the fraction $>75 \mu \mathrm{m}$. 


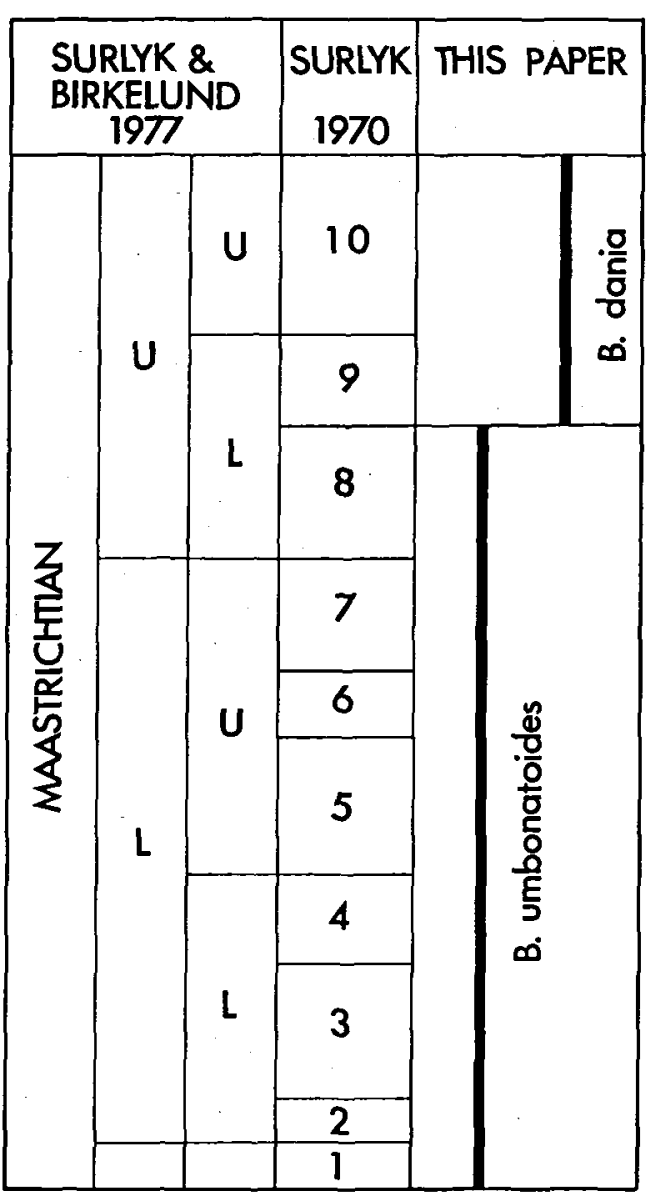

Fig. 3. The biostratigraphical zonation of the Danish white chalk.

of ostracods. The validity of these is probably restricted to the Danish basin.

A local correlation between neighbouring localities might be possible and useable as demonstrated at the Lower Maastrichtian chalk of Rügen, East Germany (Herring 1966). However, the index species in the Rügen sections are recorded from several Danish localities, although here they are without stratigraphical significance. Correlation by means of density is not recommended, owing to the considerable vertical and lateral variations.

It has not been possible to establish assemblage zones as successfully has been done in the Maastricht area (Deroo 1966). This is most likely due to the relatively short stratigraphic sequence exposed in the Danish area, and to the homogeneous environmental conditions.
A considerable similarity exists between ostracod faunas in chalk facies from Upper Cretaceous in northwestern Europe. In addition to the Maastrichtian fauna from Denmark, the chalk ostracod faunas described comprise the Lower Maastrichtian chalk of Rügen, East Germany (Herrig 1966), the Upper Campanian and Lower Maastrichtian at Mielnik, Poland (Szczechura 1964, 1966), Upper Campanian and Lower Maastrichtian in the Maastricht area, Netherlands (Deroo 1966) and the Upper Cretaceous of England (Jones \& Hinde 1890; Kay 1964). Paucity of data available does not allow a quantitative comparison of the faunas described, but although some differences in density and diversity exist, the similarity is evident at both genus and species levels.

Deroo (1966) found that the change in carbonate sedimentology in the Maastricht area reflected by 'Craie Grossière' and the 'Tuffeau de Maastricht' also involved a considerable change in the ostracod fauna. He described the profound high-diversity 'tuff-fauna' as being a typical 'tropical' neritic one and suggested ecological conditions similar to those accepted for the Lower Maastrichtian in the north Aquitanian basin. However, this southern influence did not reach other parts of the Upper Cretaceous of northwestern Europe.

The homogeneous composition of the ostracod fauna is most likely related to the basinal chalk facies that dominates the Danish Maastrichtian (Håkansson et al. 1974). The biomicrite constituted a relatively constant and uniform substrate for the benthic ostracods through Maastrichtian time, and the remarkably high diversity indicates a mature and well-balanced community. A detailed study on the ostracod diversity in the Danish Maastrichtian is in preparation.

According to known bathymetric distributions of the respective genera, the chalk ostracod fauna indicates epicontinental sublittoral environments (Moore 1961; Morkhoven 1963). There are no indications that sedimentation, in the studied sections, took place within the euphotic zone (Håkansson et al. 1974). Furthermore, the lack of typical plant dwellers indicates that the fauna studied characterizes environments below limits of algal growth i.e. middle to outer shelf conditions. 
Acknowledgements. The author is indepted to $\mathrm{H}$. Egelund for preparing the figures and to R. G. Bromley who kindly improved the English text. This study was supported by the Carlsberg Foundation.

\section{Dansk sammendrag}

Ostracodfaunaen i det danske skrivekridt (Maastrichtian) omfatter 95 arter fordelt på 34 slagter. Faunaen er karakteriseret af stor ensartethed $i$ det undersøgte område og indicerer at midt til ydre shelf forhold har rådet $i$ den danske del af Maastrichtien havet. Det danske skrivekridt kan opdeles i to zoner på grundlag af ostracodfordelingen.

\section{References}

Birkelund, T. 1957: Upper Cretaceous belemnites from Denmark. Biol. Skr. dan. Vid. Selsk. 9 (1): 1-71.

Bonnema, J. H. 1940: Ostracoden aus der Kreide des Untergrundes der nordöstlischen Niederlande. Natuurhist. Maandbl. 29: 91-95, 104-108, 115-118, 129-132.

Bonnema, J. H. 1941: Ostracoden aus der Kreide des Untergrundes der nordöstlischen Niederlande. Natuurhist. Maandbl. 30: 8-10, 21-24, 26-29, 40-43, 56-60, 70-92.

Deroo, G. 1966: Cytheracea (Ostracodes) du Maastrichien de Maastricht (Pays-Bas) et des régions voisines; résultats stratigraphiques et paléontologiques de leur étude. Meded. geol. Sticht., Maastricht 2: 1-197.

Elofson, O. 1941: Zur kenntnis der marinen Ostracoden Schwedens mit besonderer Berucksichtigung des Skagerak. Zool. Bidrag, Upsala 19: 215-534.

Herrig, E. 1966: Ostracoden aus der Weissen Schreibkreide (Unter Maastricht) der Insel Rügen. Paläont. Abh. A. (2) 4: 693-1024.

Håkansson, E., Bromley, R. \& Perch-Nielsen, K. 1974: Maastrichtian chalk of north-west Europe - a pelagic shelf sediment. Spec. Publs int. Ass. Sediment. 1: 211-233.

Jones, T. R. \& Hinde, G. J. 1890: A supplemtary Monograph of the Cretaceous Entomostraca of England and Ireland. Palaeontogr. Soc. 43: 1-70.

Jørgensen, N. O. 1970: Ostracoderne i det danske skrivekridt, deres stratigrafiske og palcookologiske betydning. $246 \mathrm{pp}$. Unpublished thesis, Copenhagen, University, Denmark.

Jørgensen, N. O. 1974: A new ostracode species from Maastrichtian white chalk of Denmark. Bull. geol. Soc. Denmark 23: 102-108.

Jorgensen, N. O. 1976: Bythoceratina dania, a new ostracode from the Maastrichtian white chalk (Denmark). Bull. geol. Soc. Denmark25: 135-137.

Kaye, P. 1964: Revision of British marine Cretaceous Ostracoda with notes on additional forms. Bull. British. Mus. nat, Hist. Geol. 10(2): 39-79.
Moore, R. C. 1961: Arthropoda. Treatise on Invertebrate Paleontology, Q. Kansas Univ. Press, 442 pp.

Morkhoven, F. P. C. van, 1963: Post-palaeozoic Ostracoda. Their morphology, taxonomy and economic use. 2 Generic descriptions, 1-478, New York: Elsevier.

Surlyk, F. 1970: Die Stratigraphie des Maastricht von Dänemark und Norddeutchland auf Grund von Brachiopoden. Newsl. Stratigr. 1(2): 7-17.

Surlyk, F. \& Birkelund, T. 1977: An intergrated stratigraphical study of fossil assemblages from the Maastrichtian white chalk of northwestern Europe. In Kauffman \& Hazel (eds): Concepts and methods of biostratigraphy. Pennsylvania: Dowden, Hutchinson \& Ross.

Szczechura J. 1964: Monoceratina Roth (Ostracoda) from the Upper Cretaceous and Lower Paleocen of north and central Poland. Acta Paleontol. Polon. 9: 357-406.

Szczechura, J. 1965: Cytheracea (Ostracoda) from the uppermost Cretaceous and the lowermost Tertiary of Poland. Acta Paleontol. Polon. 10: 451-564.

Troelsen, J. 1937: Om den stratigrafiske inddeling af skrivekridtet i Danmark. Meddr dansk geol. Foren. 9: 260-263.

van Veen, J. E. 1932: Die Cytherellidae der Maastrichter Tuffkreide und des Kunrader Korallenkalkes von Süd-Limburg. Verh. Geol. Mijnb. gen. Mederland Kolonien. Geol. 9: 317-364.

van Veen, J. E. 1934: Die Cypridae und Bairdiidae der Maastrichter Tuffkreide und des Kunrader Korallenkalkes von Süd-Limburg. Natuurhist. Maandbl. 23: 88-94, 103-110, 115-122, 128-132.

van Veen, J. E. 1935a: Die Cytheridae der Maastrichter Tuffkreide und des Kunrader Korallenkalkes von Süd-Limburg. I. Die Gattung Brachycythere. Natuurhist. Maandbl. 24: 26-28, 48-51, 56-59.

van Veen, J. E. 1935b: Die Cytheridae der Maastrichter Tuffkreide und des Kunrader Korallenkalkes von Süd-Limburg. II. Die Gattung Cytheridea. Natuurhist. Maandbl. 24: 83-88, 95-98, 106-112.

van Veen, J. E. 1936a: Die Cytheridae der Maastrichter Tuffkreide und des Kunrader Korallenkalkes von süd-Limburg. III. Die Gattungen Loxoconcha, Monoceratina, $\mathrm{Pa}$ racytheridea, Xestoleberis, Cytheropteron und Cytherura. Natuurhist. Maandbl. 25: 21-24, 32-36, 42-45, 62-64, 69-71, 82-86, 98-101, 108-113.

van Veen, J. E. 1936b: Die Cytheridae des Maastrichter Tuffkréide und des Kunrader Korallenkalkes von Süd-Limburg. IV. Die Gattungen Cythereis, Archicythereis und Cytheredeis. Natuurhist. Maandbl. 25: 131-168.

van Veen, J. E. 1936c: Die Cypridinidae der Maastrichter Tuffkreide und des Kunrader Korallenkalkes von Süd-Limburg. Naturhist. Maandbl. 25: 169-170.

van Veen, J. E. 1936d: Nachtrag zu der bisher erschienenen Tuffkreide und des Kunrader Korallenkalkes von Süd-Limburg. Natuurhist. Maandbl. 25: 170-188.

van Veen, J. E. 1938: Die Ostracoden in der Tuffkreide ohne gelbe limonitische Färbung unter dem Koprolithenschichten zu Slavante. Natuurhist. Maandbl. 27: 10-12, 15-20. 